\title{
The Validity of Student Worksheets and Student Textbooks Inquiry Training Model on The Colligative Properties of Solution
}

\author{
Putri Pratikno ${ }^{1, a *}$, Suyono ${ }^{1, b}$ \& Rudiana Agustini ${ }^{1, c}$ \\ ${ }^{1}$ Science Education Program, Postgraduate School, Surabaya State University, Surabaya, 60231, Indonesia \\ a putripratikno@mhs.unesa.ac.id; b suyono@unesa.ac.id; c rudianaagustini@unesa.ac.id \\ *Corresponding Author : putripratikno@mhs.unesa.ac.id [ Phone : 081217392795 ]
}

\begin{abstract}
This study is development research of student worksheets and student textbooks using the inquiry training model to support the learning of the colligative properties of solution. The purpose of this study was to produce valid student worksheets and student textbooks. Student worksheets and student textbooks are developed using the ADDIE (Analyze, Design, Development, Implement, and Evaluate) design. The validity measured includes construct validity and content validity. The validity of the device was assessed by three validators using a validation sheet. The validation result data were analyzed descriptively quantitative and descriptive qualitative. The results of data analysis show that the student worksheets and student books developed have reached a valid category with the mode of score ranging from 3 to 4 ..
\end{abstract}

Keywords: Student worksheets; Student textbooks; Inquiry training model; Coligative properties of solution;

\section{Introduction}

The essence of chemistry includes two things, namely chemistry as a product and chemistry as a process. Chemistry as a product includes a set of knowledge consisting of facts, concepts, principles, theories, and laws of chemistry. Chemistry as a process includes the process skills and scientific attitude that scientists have to acquire and develop chemical knowledge. Faizi (2013) states that students in carrying out chemistry learning not only learn the product but also the process of obtaining the product. Chemical knowledge can be acquired independently through discovery learning. Knowledge gained from learning discoveries will be very meaningful if it is carried out through scientific research (Ausubel in Dahar, 2006). Meaningful knowledge can be obtained if in the process of discovery it is carried out through research that applies the scientific method.

The use of the scientific method can also train science process skills and scientific attitudes. Science process skills and scientific attitudes must be possessed by students in addition to mastering concepts. This is in line with the statement expressed by Sumiyadi \& Masturi (2015) that to achieve optimal learning science, students in s amping able to master the concepts of science, also need to master the science process skills and have a scientific attitude. The scientific approach can be applied through inquiry learning. Abdi (2014) states that inquiry learning which is applied in science learning makes students carry out activities and thought processes like scientists do to find new knowledge. The inquiry learning model designed to bring students directly into the scientific process in a short period of time is the inquiry training learning model (Hutabarat \& Juliani, 201 7).

The inquiry training learning model was developed by Richard Suchman who taught a research process to explain a phenomenon. Joyce \& Weil (2003) state that inquiry training is designed to take students directly to the scientific process through exercises where the scientific process is summarized in a short period of time. The learning phase of the inquiry training model is in accordance with the scientific method so that it can facilitate students to do research to fulfill their curiosity. Providing the opportunity to do research directly makes students actively participate in learning. Arisa \& Simamora (2014) stated that student achievement using the inquiry training model was better than using the conventional model applied in the control class. In addition to being able to train skills in carrying out scientific processes and scientific attitudes, the inquiry training model can also improve students' understanding of learning material. 
One of the chemical materials that students are not familiar with is the colligative nature of solutions. This can be seen from the results of the 2016 National Examination (UN) which showed that the percentage of mastery of colligative nature in Jombang district was $36.83 \%$. It is also supported by the results of the initial trials that only $30 \%$ of students scoring above the KKM. Ratna et al. (2016) stated that the colligative nature of matter is material that is abstract, interesting, and related to everyday life. The abstract nature of the material makes students have difficulty understanding the concept so that student learning outcomes are low. The low learning outcomes can be caused by the inadequacy of the learning model or learning tools used.

Less suitable learning materials can be viewed from student textbooks, student worksheets, or learning model used. Student textbooks that students use in Trensains High School Jombang do not present prior knowledge needed to study colligative properties such as knowledge about solutions and concentration. The addition of initial knowledge can make it easier for students to recall so that the process of understanding subsequent concepts is also easier. The presentation of the concepts in textbooks is not well detailed, but student textbooks are equipped with examples of phenomena related to the colligative nature of solutions. Student textbooks are also equipped with worksheets, but only on one topic, namely freezing point reduction. The worksheets used by Trensains High School students are still in the form of traditional experimental worksheets or known as the cookbook style. Experiments are traditionally different from scientific experiments. Experimental activities with the cookbook style only focus on terminology, facts, and concepts, detailed procedures, giving direction to what students will observe (Ural, 2016). Teachers in experimental activities traditionally have a role as a source of information that provides direction on what to do and what results are expected. Experiments do not traditionally help students discover knowledge scientifically and cannot train students' scientific process skills. Knowledge whose discovery process that is not scientific will have low meaning in the minds of students. The facts presented above can lead to low student learning outcomes. Based on the above explanation, the researchers intend to develop pieces of work students a model of inquiry training which aims to improve the outcomes of learning chemistry students.

\section{Research Methods}

This research is development research to produce student worksheets and student textbooks using the inquiry training model on the material colligative properties of solutions. The development of student worksheets and student textbooks uses the ADDIE design, which consists of five stages, namely: (1) analyze; (2) design; (3) develop; (4) implement; and (5) evaluate (Branch, 2009). The ADDIE design discussion will be limited to the develop stage because this article focuses on the explanation of the validation of student worksheets and student textbooks that have been developed at that stage.

Analyze stage consists of needs analysis, analysis, students, task analysis, and material analysis. The design stage aims to design the basic forms of student worksheets and student textbooks to be developed. This stage consists of formulating learning objectives, determining learning models, and developing student worksheets and student textbooks. The develop stage consists of developing student worksheets and student textbooks, validating student worksheets and student textbooks, and revising student worksheets and student textbooks. This stage will produce a product that has gone through a validation and revision process based on suggestions from the validator.

The validation was carried out by three chemistry lecturers at the State University of Surabaya. The validator gives a score ranging from 1 to 4 according to the criteria on the validation sheet. Validators can also provide suggestions and improvements for the student worksheets and student books being developed. The validation result data were analyzed descriptively quantitative and descriptive qualitative. The quantitative descriptive analysis uses the mode of the score given by the validator for each aspect to be categorized as in Table 1.

Table 1. Criteria for The Validity of Student Worksheets and Student Textbooks

\begin{tabular}{cc}
\hline Score Interval & Category \\
\hline $3,6 \leq$ score $\leq 4,0$ & Very Valid \\
\hline $2,6 \leq$ score $<3,6$ & Valid \\
\hline $1,6 \leq$ score $<2,6$ & Less Valid \\
\hline $1,0 \leq$ score $<1,6$ & Invalid \\
\hline
\end{tabular}

(Ratumanan \& Laurens, 2011)

Based on Table 1, it is known that student worksheets and student books are said to be valid and can be used in learning activities if each aspect reaches a minimum score of 2.6. 


\section{Results And Discussions}

\subsection{Validity of Student Worksheets}

The Regulation of the Minister of Education and Culture (2016) defines student worksheets as student guides for conducting scientific experimental activities. Student worksheets can help teachers lead students to carry out learning activities to achieve learning goals. Student worksheets are a form of means to help and facilitate the implementation of learning so that effective interactions are formed between teachers and students and students and other students and can increase student activity (Dewi, 2013). Student worksheets developed using the inquiry training model on the colligative nature of the solution for four meetings. The results of construct validation of the student worksheet can be seen in Figure 1.

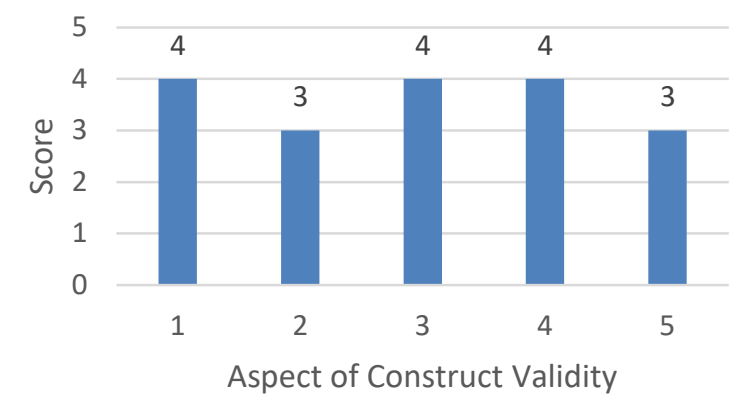

Figure 1. Results Construct Validity of Student Worksheets

Figure 1 shows that of the five aspects of construct validation, three aspects get the mode of a score of 4 with a very valid category. These aspects are the first, third, and fourth aspects. The first aspect is regarding the achievement of learning objectives, this aspect is categorized as very valid because the learning steps on the worksheet can help students achieve learning goals. The learning steps on the worksheet are adjusted to the learning phase of the inquiry training model which includes: (1) confronting a problem, (2) collecting data-verification, (3) collecting experimental data, (4) organizing data and compiling explanations, and (5) analyzing the inquiry process (Joyce \& Weil, 2003). The inquiry training learning phase can help students conduct scientific experiments and make it easier for students to gain meaningful knowledge that is in accordance with the learning objectives. The third aspect is about the ease of questions on student worksheets to achieve learning objectives and the fourth aspect is about student direction to strengthen concept understanding. Questions on student worksheets are a form of learning with assistance according to Vygotsky's theory. Questions on the worksheet can lead students to conduct experiments and compile an explanation of the experimental results. Nur (2008) states that these questions can make it easier for students to thoroughly master skills that allow higher cognitive function.

Two other aspects obtain the mode of a score of 3 with the valid category are the second and fifth aspects. The second aspect concerns the systematic, logical, and straightforward presentation of problems or phenomena, while the fifth aspect concerns the sentence rules used. Both of these aspects get a score that is not perfect because it is necessary to improve the phenomenon on the worksheets of first and second meetings. This phenomenon on the worksheet needs to be corrected because sentences are less easy to understand and can lead to multiple interpretations. Further discussion regarding content validation. Content validation is based on aspects of the relevance of worksheets with scientific principles regarding the inquiry training learning model, meeting the needs of learning outcomes, and chemical concepts in this case regarding the colligative nature of solutions. The results of validation contents of the student worksheets can be seen in Figure 2.

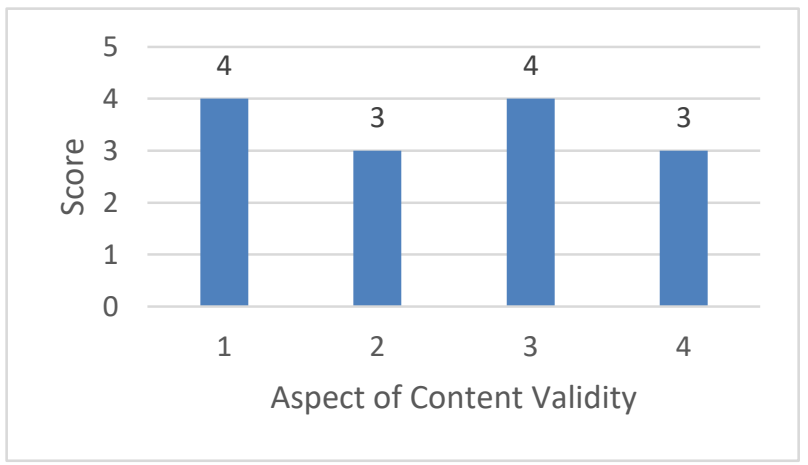

Figure 2. Results Content Validity of Student Worksheets 
Figure 2 shows that two aspects from four aspects get the mode of a score of 4 with very valid categories, namely the first and third aspects. The first aspect, which is about each component or activity on the worksheet, is based on strong theoretical arguments about the inquiry training learning model. Another aspect that is categorized as very valid is the third aspect regarding the worksheets developed that has fulfilled the need for learning outcomes. The developed student worksheets are in accordance with the inquiry training learning model. Inquiry training model worksheets can help students achieve learning outcomes because with this model students will gain meaningful knowledge through scientific activities. This is in line with what Singh (2016) stated that the learning achievement of students who use the inquiry training model of learning is better than students who use conventional learning. Students' science process skills can also be trained in this learning model, as stated by Saanatun (2017) that the science process skills of students who use the inquiry training model are better than students who use conventional learning.

The learning steps on the student worksheets are adjusted to the learning phase of the inquiry training model. The first step on the worksheet asks students to read a phenomenon that has been provided, then students are asked to formulate a problem about that phenomenon. This first step is in accordance with the first phase of the inquiry training model, which is confronting a problem.

The second step on the worksheet directs students to create a frame of mind and continue formulating hypotheses. The step after formulating the problem is formulating a hypothesis, but before that students must first make a frame of mind. The thinking frame is made with the aim that the student's hypothesis at the next stage is correct. Students can create a thinking frame by first reading the students' books related to phenomena in the first step. The student worksheet already contains instructions that require students to read the student's book before making a frame of mind, this instruction is equipped with a page in the student book that must be read, so students will not experience confusion. This second step is in accordance with the second phase of the inquiry training model, namely data collection-verification.

The third step on the worksheet asks students to identify variables, draw a series of practicum tools, and arrange the steps for practicum activities. If the hypothesis already exists, then it is continued by identifying the variables. The variables identified include manipulation, response, and control variables. The list of tools and materials used is already on the worksheet so that students can draw a series of practicum tools and arrange the steps for practicum activities according to the list. This third step is in accordance with the third phase of the inquiry training learning model, namely collecting practicum data.

The fourth step on the worksheet directs students to organize the data from the practicum, analyze the data, and compile conclusions. Students can organize the data obtained in tabular form to make it easier to understand. The next activity is to analyze the data from the practicum. The data analysis section on the worksheet contains questions that can lead students to more easily analyze data from practicum results. Students can make conclusions based on the data analysis that has been done. This fourth step is in accordance with the inquiry training learning phase, namely organizing data and compiling explanations.

The fifth step on the student worksheet asks students to analyze the process of inquiry students have done from steps one to four. Students are asked to analyze whether the conclusions generated in the fourth step are in accordance with the hypotheses compiled in the second step. If the conclusions are not in accordance with the hypothesis, students are asked to analyze the inquiry process that has been carried out to find the cause of the mismatch. This final step is also in accordance with the inquiry training learning phase, namely analyzing the inquiry process.

Joyce \& Weil (2003) explain that inquiry training learning can train students to find answers to their curiosity systematically according to a scientific process. The developed student worksheets are made in such a way as to make it easier for the teacher to practice the inquiry process. The worksheets that are created contain gradual assistance provided by the teacher to practice the inquiry process. The assistance provided on the first worksheet consists of a list of tools and materials, a series of practical tools, work steps, and a table of observations. The assistance provided on the second worksheet consists of a list of tools and materials, a series of practicum tools, and a table of observation results. Students at the second meeting were asked to arrange their work steps. The assistance provided in the third worksheet consists of a list of tools and materials and a table of observations. Students at the third meeting were asked to draw a series of practicum tools and arrange their work steps. The assistance provided on the fourth worksheet is only a list of tools and materials. Students at the fourth meeting were asked to draw a series of practicum tools, arrange work steps, and make tables of their observations. The worksheets that have been developed are expected to help teachers practice the process of inquiry step by step.

\subsection{Validity of Student Textbooks}

Arifin \& Kusrianto (2008) states that student textbooks are organized according to the needs of students to achieve the learning goals. Hanifah (2014) added that student textbooks are one of the supporting factors for 
success in achieving learning goals. Student books developed in this study contain material colligative properties of solution. The results of construct validation of the student textbooks can be seen in Figure 3 . Figure 3 shows that there are sixteen aspects from nineteen aspects that get the mode of a score of 4 with a very valid category, while the other three aspects get the mode of a score of 3 with a valid category. The discussion of the nineteen aspects will be grouped into six discussion points to make it easier to understand.

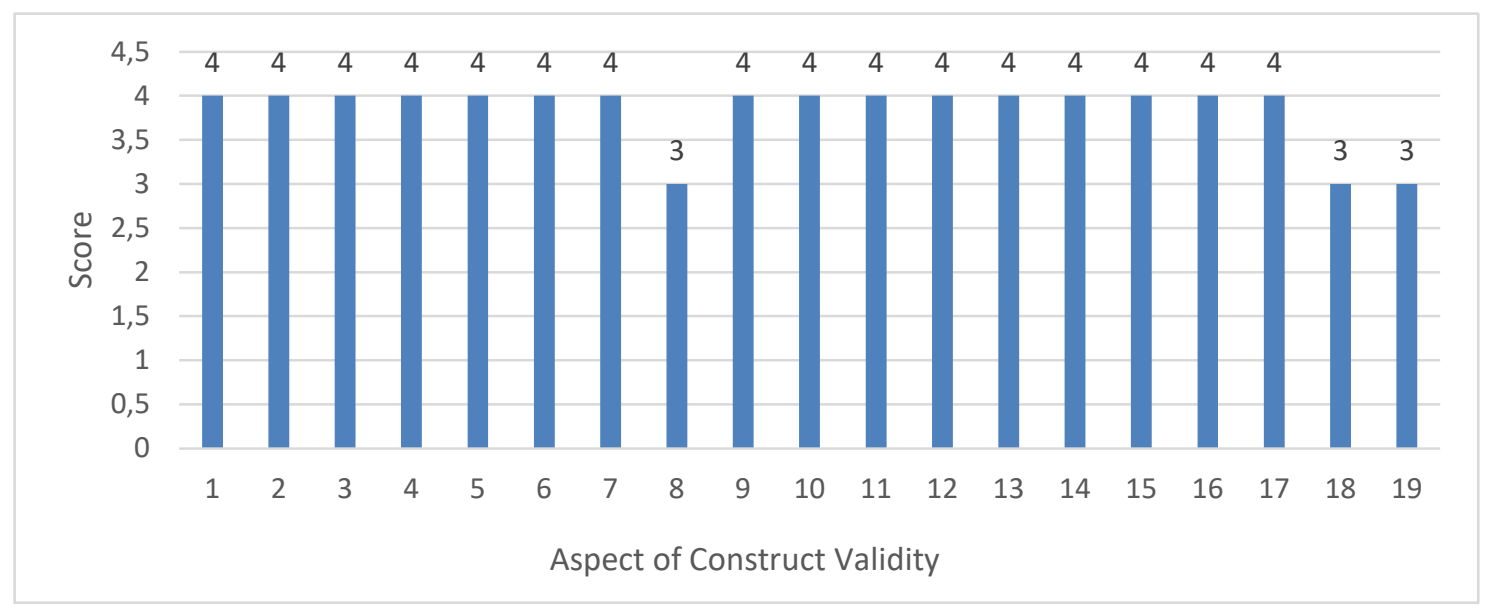

Figure 3. Results Construct Validity of Student Textbooks

The first discussion regarding the supporting facilities for the presentation of material which includes aspects number 1,2, and 3 . The first aspect regarding the presentation of the concept map gets the mode of a score of 4 which theoretically falls into the very valid category. The second aspect regarding the presentation of the image gets the mode of a score of 4 which theoretically falls into the very valid category. The third aspect regarding the presentation of the "Info Kimia" column gets the mode of a score of 4 which in theory falls into the very valid category. The tests showed that the three aspects of the respective gain the mode of a score of 4 which means that the students developed textbooks can be used by students as learning activities as it can support the presentation of material to students.

The second discussion concerns facilities for achieving knowledge competency indicators which include aspects number $4,5,6$, and 7 . The fourth aspect concerning the use of mole fraction, molality, and molarity in determining the concentration of the solution, obtained the mode of a score of 4 which theoretically falls into the very valid category. The fifth aspect, explaining the effect of solutes on vapor pressure, boiling point, freezing point, and osmotic pressure, obtains the mode of a score of 4 which theoretically falls into the very valid category. The sixth aspect about explaining the different effects of solutes with different concentrations on vapor pressure, boiling point, freezing point, and osmotic pressure, obtains the mode of a score of 4 which theoretically falls into the very valid category. The seventh aspect regarding the explanation of the difference in the effect of the presence of solutes of different properties (electrolyte and non-electrolyte) but with the same concentration on vapor pressure, boiling point, freezing point, and osmotic pressure, obtains the mode of a score of 4 which theoretically falls into the very valid category. The results of the validation show that for the four aspects, each of them obtained the mode of a score of 4 in the very valid category. Based on this assessment, the developed student textbooks can be used by students during learning activities because it can facilitate students to achieve knowledge competency indicators.

The third discussion concerns facilities for the achievement of competencies attitude indicator which includes aspects number 8, 9, 10, and 11. The eighth aspect of the presentation of the "Kajian Islam" column to establish a spiritual attitude of students, obtained the mode of a score of 3 theoretically get into the valid category. Improvements for this aspect are carried out by adding the meaning of the verses of the Qur'an that are listed in the student textbooks according to the validator's notes. The ninth aspect of the presentation of the "Perlu diingat" column to remind students to have an attitude of saving use of natural resources, gain the mode of a score of 4 theoretically fit into the category of very valid. The tenth aspect of the presentation of the "Perlu diingat" column to remind students to have an attitude of care for the environment, gain the mode of a score of 4 theoretically fit into the category of very valid. The eleventh aspect of the presentation of the "Perlu diingat" column to remind students to have a critical attitude, obtaining the mode of a score of 4 theoretically fit into the category of very valid. The results of the validation show that for the four aspects assessed, only one aspect has obtained a valid category, while the other three aspects have obtained a very valid category. Based on this assessment, the developed student book can be used by students during learning activities because it can facilitate students to achieve attitudinal competency indicators, but improvements in one aspect need to be made according to the explanation above. 
The fourth discussion concerns the requirements as a textbook that covers numbers 12, 13, 14, 15, 16, and 17. The twelfth aspect of the presentation of the facts, theories, principles, and laws, obtaining the mode of a score of 4 which theory falls into the very valid category. The thirteenth aspect of the presentation of the "Latihan Memahami" column to help students understand the concepts, gain the mode of a score of 4 that theoretically fit into the category of very valid. The fourteenth aspect of the presentation of the "Rangkuman" column to help students see the entire core material, obtained the mode of a score of 4 theoretically fit into the category of very valid. The fifteenth aspect of the presentation of the "Uji Kompetensi" column to measure student understanding, gain the mode of a score of 4 that theoretically fit into the category of very valid. The sixteenth aspect of the presentation of material by using the phrase for a simple, easy to understand and communicative, obtaining the mode of a score of 4 theoretically fit into the category of very valid. The seventeenth aspect regarding the conciseness of the presentation of the material obtains the mode of a score of 4 which theoretically falls into the very valid category. The results of the validation show that for the six aspects assessed, each of them obtains the mode of a score of 4 with a very valid category. Based on this assessment, the developed student textbooks can be used by students during learning activities because it meets the requirements as a textbook.

The fifth discussion about the presentation of guidance as an inquiry which is an the eighteenth aspect gain the mode of a score of 3 which theoretically belongs to the valid category. This judgment states that the presentation of the "Praktikum" column which contains questions to encourage students to find the answer through experimentation is good, in the column can be added the phenomenon in accordance with what is written in the student worksheet to attract more attention or curiosity of students.

The sixth discussion about the presentation of online learning which is the nineteenth aspect obtains the mode of a score of 3 which theoretically falls into the valid category. This assessment showed that the presentation of the "Chemistry Online" column to encourage students to do the learning online when outside school hours already good. Improvements in this aspect were carried out in accordance with the validator's notes by including the complete website address in the "Chemistry Online" column so that students could easily access it. The result of content validation of student textbooks can be seen in Figure 4 .

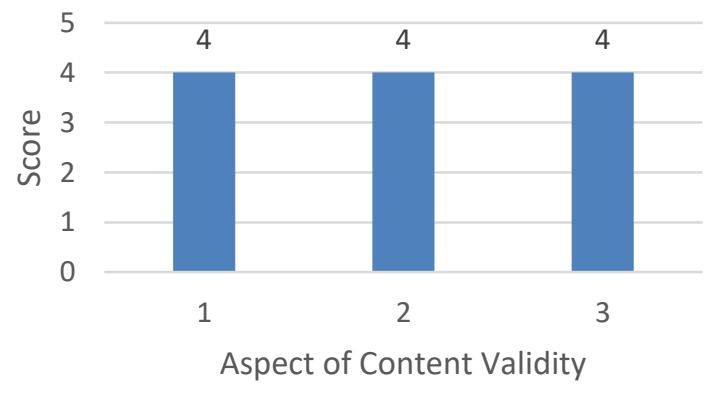

Figure 4. Results Content Validity of Student Textbooks

Figure 4 shows the results of validating the content of students textbooks by the validator in all aspects of content validity. The first aspect is validated that each component of the student book is based on a strong theoretical argument about the learning model inquiry training, obtaining the mode of a score of 4 theoretically fit into the category of very valid. The second aspect is validated namely student books developed provides the fulfillment of the learning outcomes of students, obtained the mode of a score of 4 theoretically fit into the category of very valid. The third aspect is validated chemical materials that become content in the student textbooks suit with the rules of chemical science, obtaining the mode of a score of 4 theoretically fit into the category of very valid.

The construct validation of the student textbooks which consists of 19 aspects, most of which have obtained the valid category. The content validation of student textbooks which consists of 3 aspects, obtained a very valid category. This assessment shows that the student book can and is suitable for use in learning. Improvements in several aspects that need to be needed to improve the quality of student textbooks. The developed student book contains several provisions determined by the Ministry of National Education and has been validated so that the results are valid and suitable for use. Ministry of National Education and Culture (2016) teaching materials should pay attention to (a) layout, including easy sequence, short title, table of contents, clear cognitive structure, summary, and reader's assignments; (b) easy language, including flow of vocabulary, short, clear, and interrelated sentences; (c) testing understanding, including, assessing through readers, checklist of understanding; (d) stimulant, (relating to an attractive appearance, writing encourages readers to think and test stimulants); (e) readability, such as eye-friendliness (font size and readability) structured text sequence; (f) instructional materials, including text selection, study materials, worksheets. 


\section{Conclusion}

Based on the results of research and discussion, it can be concluded that the worksheets and student textbooks with the inquiry training learning model on the colligative nature of the solution are valid. Worksheets and student textbooks can be used in learning activities.

\section{References}

Abdi, A. (2014). The Effect of Inquiry Based Learning Method on Students Academic Achievement in Science Course. Journal of Educational Research. 2(1), 37-41.

Arifin dan Kusrianto. (2008). Sukses Menulis Buku Ajar dan Referensi. Jakarta: PT Gramedia Widiasarana Indonesia.

Arisa, Y. dan Simamora, P. (2014). Pengaruh Model Pembelajaran Inquiry Training Terhadap Hasil Belajar Siswa Pada Materi Pokok Fluida Statis. Jurnal Inpafi. 2(4), 54-60.

Branch, R. M. (2009). Instructional design: ADDIE approach. New York: Springer Science \& Business Media.

Dahar, R. W. (2011). Teori-teori belajar E pembelajaran. Jakarta: Erlangga.

Dewi, D. R. (2013). Pengembangan Lembar Kerja Siswa Untuk Pembelajaran Permutasi dan Kombinasi Dengan Pendekatan Kontekstual Untuk Siswa SMA Kelas XI. Diunduh dari http://jurnalonline.um.ac.id/data/artikel/artikelD2AB962FB03A2AA96B84726445FC4901.pdf.

Faizi, M. (2013). Ragam Metode Mengajar Eksakta pada Murid. Yogyakarta : Diva Press.

Hutabarat, F.I. dan Juliani, R. (2017). Pengaruh Model Pembelajaran Inquiry Training Terhadap Hasil Belajar Siswa Pada Materi Pengukuran. Jurnal Pendidikan Fisika. 6(1), 13-21.

Joyce, B. dan Weil, M. (2003). Models Of Teaching $5^{\text {th }}$ Edition. New Delhi : Prentice Hall.

Nur, M., \& Wikandari, P. R. (2008). Pengajaran Berpusat Kepada Siswa dan Pendekatan Konstruktivis dalam Pengajaran Edisi Kelima. Surabaya: PSMS Universitas Negeri Surabaya.

Peraturan Menteri Pendidikan dan Kebudayaan Nomor 22. (2016). Tentang Standar Proses Pendidikan Dasar dan Menengah. Jakarta : Depdiknas.

Ratna, Cawang, dan Fitriani. (2016). Pengaruh Pendekatan Inkuiri Terhadap Kemampuan Retensi Siswa Pada Materi sifat Koligatif arutan Kelas XII IPA SMA Muhammadiyah 2 Pontianak. Ar-Razi Jurnal Ilmiah. 4(2), 118-127.

Ratumanan, G. T. dan Laurens, T. (2011). Penilaian Hasil Belajar Pada Tingkat Satuan Pendidikan Edisi 2. Surabaya: UNESA University Press.

Saanatun. (2017). Model Pembelajaran Inquiry Training Dengan Menggunakan komik Fisika Dan Kreativitas Terhadap Keterampilan Proses Sains. Jurnal Pendidikan Fisika, 6(1), 8-12.

Singh, V. (2016). Effectiveness of Inquiry Training Model For Teaching Chemistry. Scholarly Research Journal For Interdisciplinary Studies, 2(15), 2344-2349.

Sumiyadi, Supardi, I. K., dan Masturi. 2015. Pengembangan Perangkat Pembelajaran IPA Berbasis Inkuiri dan Berwawasan Konservasi. Journal of Innovative Science Education. 4(1). Diunduh dari https://journal.unnes.ac.id/sju/index.php/jise/article/view/6894/5839.

Ural, E. (2016). The effect of guided inquiry experiments on science education students' chemistry laboratory attitudes, anxiety, and achievement. Journal of Education and Training Studies, 4(4), 217-227. 